\title{
GROWTH-YIELD RELATIONSHIP OF GRAPEVINE CULTIVARS ON SOILS WITH HARDENED LAYERS, ALTO VALLE OF THE RÍO NEGRO, SOUTHERN WINE-GROWING REGION OF ARGENTINA
}

\author{
Equilibrio vegetativo-productivo en cultivares de vid sobre suelos con capas \\ endurecidas, Alto Valle de Río Negro, región vitivinícola sur de Argentina
}

\author{
María del C. Echenique ${ }^{1 *}$, Alicia Apcarian ${ }^{1}$, Pablo Reeb $^{1}$ y María C. Aruani ${ }^{1}$
}

\begin{abstract}
A B S T R A C T
The aim of this work was to evaluate the vegetativeproductive balance of Vitis vinifera L. cvs. Merlot, Malbec and Cabernet Sauvignon on Aridisols with hardened layers in the Alto Valle of Río Negro, Argentina. The study was carried out in 15.5 ha of vineyards during 2002-2003 on five soil groups characterized by: type, thickness and depth of the horizons, texture and resistance to penetration. In each sampling site three plants were evaluated. Production, leaf area, pruning material, trunk diameter, the Ravaz Index, the leaf area/yield ratio and the leaf area index were determined. A variance analysis and means comparison were made. The production level, the leaf area and the pruning material of the three cultivars were reduced $(\mathrm{P}<0.05)$ when the soils presented extremely hard horizons (resistance to penetration greater than $3 \mathrm{MPa}$ ) at a depth of $35 \mathrm{~cm}$ or less and with $30 \mathrm{~cm}$ or more of thickness, indicating a low site potential. The Ravaz Index and the leaf area/yield ratio didn't show differences $(\mathrm{P}<0.05)$ among soil groups in any cultivar. In soils with restricted properties, but with an adequate growth-yield balance, smaller vine spacing and avoiding gaps between vines can be used to increase production.
\end{abstract}

Key words: Vitis vinifera, leaf area, pruning material, vegetative-productive balance, soil characteristics.

\section{R E S U M E N}

El objetivo de este trabajo fue evaluar el equilibrio vegetativo-productivo de Vitis vinifera L. cvs. Merlot, Malbec y Cabernet Sauvignon sobre Aridisoles con capas endurecidas del Alto Valle de Río Negro, Argentina. El estudio se realizó en 15,5 ha de viñedos durante la temporada 2002-2003 sobre cinco grupos de suelos, caracterizados por: tipo, espesor y profundidad de los horizontes, textura y resistencia a la penetración. En cada sitio de muestreo, se evaluaron tres plantas para cada uno de ellos, determinando: producción, área foliar, peso del material de poda por planta, diámetro de tronco, índice de Ravaz, relación área foliar/peso de la producción e índice de área foliar. Se efectuó un análisis de varianza y una comparación de medias de las variables del cultivo según cada grupo de suelos. El nivel de producción, el área foliar y el peso de material de poda por planta de los tres cultivares resultaron disminuidos cuando los suelos presentaron horizontes extremadamente duros (resistencia a la penetración superior a $3 \mathrm{MPa}$ ) a menos de 35 $\mathrm{cm}$ de profundidad y con espesores mayores a $30 \mathrm{~cm}$, indicando un bajo potencial vitícola de estos suelos. El índice de Ravaz y la relación área foliar/peso de la producción no mostraron diferencias $(\mathrm{P}<0,05)$, manteniéndose relaciones de equilibrio vegetativo-productivo similares entre los grupos de suelos, aunque éstos implicaran diferentes potenciales vitícolas. En suelos con propiedades limitantes, pero con un adecuado balance vegetativo-productivo, se pueden utilizar menores espaciamientos entre cepas y evitar espacios vacíos para incrementar los rendimientos por hectárea.

Palabras clave: Vitis vinifera, área foliar, material de poda, equilibrio vegetativo-productivo, características del suelo.

\footnotetext{
${ }^{1}$ Universidad Nacional del Comahue, Facultad de Ciencias Agrarias, CC 85 (8303), Cinco Saltos, Argentina. E-mail: echenique@speedy.com.ar *Author for correspondence. Received: 10 March 2006. Approved: 25 August 2005.
} 


\section{INTRODUCTION}

Several authors (Smart et al., 1985; Gómez-Miguel and Sotés Ruiz, 2000; Hunter and Archer, 2001a; $2001 \mathrm{~b})$ recognize that permanent factors related to environmental conditions (climate, soil, geology) influence the quality of harvest of Vitis vinifera $\mathrm{L}$. It is widely accepted that the same variety, with identical technology, produces wines with their own unique characters, according to the region or territory of origin. Although the concept of territory is complex and involves numerous factors, soil is an important aspect.

Smart et al. (1985), Hunter and Archer (2001a) and Kobus (2002), among others, point to the chemical composition, depth, texture and the supply of water and nutrients as edaphic factors that condition the cultivar. In Chile, Ruiz (2000) states that favorable physical characteristics of the soil and the fertility profile influence the quality of the radicular system, defining in this way in great measure the development and vigor of the plants; and Flores (2005) indicates that with cv. Cabernet Sauvignon, production factors, such as the number of clusters, are spatially correlated with physical and chemical properties of the soil.

White (2003) argues that given that the vine is a perennial cultivar, which will maintain its commercial value for more than 40 to 50 years, the relationship between the soil and the vineyard should be as harmonious as possible. The same author maintains that the availability of water and nutrients in the soil influences the vigor, yield, quality of production and the vegetative-productive balance, this latter being important for sustainable production and ensuring the longevity of the vine.

Howell (2001) gathers from diverse studies that the concept of a balanced vine is linked to the distribution of carbohydrates in the plant, and that this aspect could be interpreted through factors such as the Ravaz Index and leaf area/yield ratio $\left(\mathrm{cm}^{2} \mathrm{~g}^{-1}\right)$ at harvest time. It is accepted that in balanced vines the Ravaz Index, calculated as the coefficient between production per plant and the weight of the pruning material corresponding to the annual growth cycle, takes acceptable values between 3 and 10 (Cavagnaro et al., 1997; Main et al., 2002), and optimal values between 5 and 7 (Ravaz, 1903, cited by Vasconcelos and Castagnoli, 2001), while values greater than 10 indicate a lack of vigor, and those less than 3 indicate an excess of the same, to the detriment of the yield. The vegetative-productive balance is also considered as the quantity of leaf area required to bring a unit of ripening production. The literature cites ranges from 7 to $14 \mathrm{~cm}^{2}$ of leaf area per gram of fresh weight of production, depending on the situation of the particular cultivar. Conditions of intense light and a long growing period require a lower ratio than the inverse conditions.

While various authors have studied the diverse effects of soils on vines, there are few works on the zone of Alto Valle of Río Negro and Neuquén, where a process of recovery of wine-growing activity has begun in recent years, predominantly based on varieties with good enological qualities. Recently, research has begun about characteristics of soils that affect vegetative and productive aspects of red wines growing in the region. Apcarian et al. (2006) studied the effect of soils with hardened layers on the production and quality of $V$. vinifera cvs. Merlot, Malbec and Cabernet Sauvignon, and found that the depth, thickness and resistance to penetration of hardened horizons affect production, with greater influence on factors of yield than on the quality of cultivars.

Since vigor, leaf development and yield can be affected by distinct properties of the soil, influencing the regularity of the grape-harvests obtained, the objective of this work was to evaluate the level of vegetative and productive expression and their relationships of balance in Merlot, Malbec and Cabernet Sauvignon cultivars growing on Aridisoles with hardened layers.

\section{MATERIALS AND METHODS}

The study was carried out during the 2002-2003 season on 15.5 hectares of vineyards planted in 1979 , belonging to the same wine-growing company, in the Alto Valle of Río Negro $\left(39^{\circ} 05^{\prime}\right.$ lat. S., $67^{\circ} 09^{\prime}$ long. W.), in southern Argentina. They are located on a fluvial terrace in the cartographic units of Cervantes and Roca, which respectively have 70 and $40 \%$ of hardened horizons of genetic origin. The climate of the area is characterized by an average annual precipitation of $246.7 \mathrm{~mm}$, concentrated in autumn and spring, and a high level of evapotranspiration, accentuated by almost continual wind action. The annual mean temperature is $14.2^{\circ} \mathrm{C}$, the temperature range between day and 
night is $16^{\circ} \mathrm{C}$, and the annual hydric deficit is 550 $\mathrm{mm}$ (Servicio Meteorológico Nacional, 1992). The edaphic climate is defined as aridic and thermic, making irrigation essential for cultivation.

The cultivars analyzed were Merlot, Malbec and Cabernet Sauvignon. They are sustained by a vertical trellis system of three wires with Guyot pruning system of four canes. The distance between rows is $2.4 \mathrm{~m}$ and with $2 \mathrm{~m}$ between plants. The number of buds left after pruning is related to the vigor of the pruned plants. During the analyzed cycles the three cultivars received five gravitational irrigations in October, November, December, January and February, with $100 \mathrm{~mm}$ in each turn. An additional irrigation was applied to the cv. Cabernet Sauvignon in March. Two phytosanitary treatments were carried out for disease control with a micronized sulpher base. The cultivars were fertilized with 70 units of nitrogen, distributed in 40 and 30 units, applied in spring and autumn, respectively. During the vegetative period, a brush cutter was used on the natural green cover, while a herbicide was applied in the line of planting for weed control.

Sixty-one sampling sites were established, which were determined according to a randomly stratified sampling scheme, including one site of 50 by $50 \mathrm{~m}$ among the 15.5 hectares of the study, where the characteristics of the soil and of the cultivar were measured.

\section{Soils determinations}

The soil profiles of each site were described up to a depth of $60 \mathrm{~cm}$ and subsequently a drill was used to detect the presence or absence of gravel and/or a phreatic layer to a depth of $2 \mathrm{~m}$. The characteristics of the soil which influence rooting and the availability to water, nutrients and oxygen were analyzed: among these characteristics were the type of horizon (A, Bt, Bw, C and transitional), thickness and texture of the same, depth and thickness of the most hardened and/or densified horizon of each profile, carbonates and depths to mottles, to gravel and the phreatic layer. At the same time, the resistance to penetration of each horizon was measured, with six replicates, using an analogic cone penetrometer (ASAE S 313, Dickey-John, Auburn, Illinois, USA) with a humidity content close to field capacity, in the range of -40 to $-50 \mathrm{kPa}$. Soils were described according to the USDA (Schoeneberger et al., 1998) and were classified to the level of family according to Soil Taxonomy (Soil Survey Staff, 1996). In an earlier work by the authors (Apcarian et al., 2006), these characteristics were evaluated using a multivariate analysis of the main components, which resulted in the definition of five groups of sites with similar soils characteristics and one site pertaining to $\mathrm{cv}$. Merlot that remained isolated from the rest (site 9). Table 1 presents the average values obtained for the morphological and physical characteristics of each soil group that were significant in explaining variability among the sites.

All of the soils of the study belong to the Aridisol order. Soils with silty soils textural classe predominate. They have distinct degrees of evolution (Btn or Bw), often with hardened horizons, of two types: a) fragipans with a fragipans with a platy structure, brittle at moist, with marked redoximorphic features and illuviation at times; b) cemented calcrets with $\mathrm{CO}_{3} \mathrm{Ca}$, whose degree of cementation is more pronounced in depressed areas of the landscape. The soils are often salinated and sodified (Btn), with accentuated redoximorphic features according to their position in the landscape. Soils are mostly Natrargids (Durinodic and Aquic) (36 sites) and Haplocambids (Durinodic, Aquic and Typic) (18 sites), and with lower presence, in depressed areas in the landscape are found Aquic Durinodic Haplocalcids (three sites). The presence of Sodic Aquicambids was detected in only one site.

For each resulting group of soils, the chemical properties of the surface horizon $(\mathrm{AH})$ were analyzed in profile modalities, which are also presented in Table 1. The organic material (OM) (Walkey and Black), total nitrogen (Nt) (Kjeldahl), exchange potassium (in ammonia acetate), $\mathrm{pH}$ was measured in a paste of saturated soil using a glass electrode, and electric conductivity (EC) was measured with a conductimeter (United States Salinity Laboratory Staff, 1954) were determined. In general, the soils have neutral $\mathrm{pH}$, are well-provided with potassium and poorly to moderately provided with organic material and nitrogen. Groups 2 and 4 are lightly to moderately salinated, respectively.

Determinations on the crop. In each soil sampling site three consecutive plants were analyzed, corresponding to the row located to the left of the fixed between rows sampling point. The total number 
Table 1. Mean values of morphologic, physical and chemical characteristics of each soil groups. Alto Valle de Río Negro, Argentina.

Cuadro 1. Valores medios de características morfológicas, físicas y químicas de cada grupo de suelos. Alto Valle de Río Negro, Argentina.

\begin{tabular}{|c|c|c|c|c|c|c|c|c|c|}
\hline \multicolumn{4}{|c|}{ Morphological and physical variables } & \multicolumn{5}{|c|}{$\begin{array}{c}\text { Chemical variables } \\
\text { (measured in A horizon) }\end{array}$} & \multirow[b]{2}{*}{$\begin{array}{r}\mathbf{C E}^{(2)} \\
\mathrm{dS} \mathbf{m}^{-}\end{array}$} \\
\hline $\begin{array}{c}\text { AHT } \\
\text { cm }\end{array}$ & $\begin{array}{c}\text { PHD } \\
\text { cm }\end{array}$ & $\begin{array}{c}\text { EHD } \\
\text { cm }\end{array}$ & $\begin{array}{l}\text { RHD } \\
\text { MPa }\end{array}$ & $\begin{array}{c}\text { OM } \\
\%\end{array}$ & $\begin{array}{l}\mathrm{Nt} \\
\%\end{array}$ & $\begin{array}{c}\mathrm{K} \\
\left(\mathrm{cmol} \mathrm{kg}^{-1}\right)\end{array}$ & pH & $\begin{array}{c}\mathrm{CE}^{(1)} \\
\mathrm{dS} \mathbf{m}^{-1}\end{array}$ & \\
\hline \multicolumn{10}{|c|}{ Group 1 Dominated by Durinodic Natrargids over Aquic Natrargids, fine silty (26 sites) } \\
\hline 18 & 19 & 32 & 3.13 & 1.19 & 0.09 & 2.41 & 7.2 & 3.25 & 4.09 \\
\hline \multicolumn{10}{|c|}{ Group 2 Dominated by Aquic Natrargids over Durinodic Natrargids, fine silty (13 sites) } \\
\hline 23 & 35 & 22 & 2.6 & 1.7 & 0.11 & 2.72 & 7 & 5.75 & 5.51 \\
\hline \multicolumn{10}{|c|}{ Group 3 Dominated by Aquic Haplocambids over Typic Haplocambids, silty over coarse loamy (10 sites) } \\
\hline 17 & 26 & 18 & 2.46 & 2.32 & 0.12 & 2.4 & 7.24 & 2.58 & 3.87 \\
\hline \multicolumn{10}{|c|}{ Group 4 Durinodic Haplocambids, coarse silty ( 8 sites) } \\
\hline 28 & 45 & 26 & 2.67 & 2.63 & 0.14 & 2.38 & 7.02 & 8.63 & 9.27 \\
\hline \multicolumn{10}{|c|}{ Group 5 Aquic Durinodic Haplocalcids, coarse silty (3 sites) } \\
\hline 15 & 33 & 36 & 3.36 & 1.94 & 0.09 & 2.21 & 7.21 & 3.8 & 0.97 \\
\hline \multicolumn{10}{|c|}{ Site 9 Sodic Aquicambids, fine silty over coarse loamy } \\
\hline 15 & 70 & 60 & 3.2 & 0.43 & 0.10 & 0.9 & 7.08 & 3.48 & 3.53 \\
\hline
\end{tabular}

AHT: A horizon thickness; PHD: depth to the most hardened/densified horizon; EHD: thickness of the most hardened/densified horizon; RHD: resistance to penetration of the most hardened/densified horizon; OM: organic matter; Nt: total nitrogen; K: exchangable potassium; $\mathrm{pH}$ : $\mathrm{pH}$ in saturated paste; $\mathrm{EC}$ : electrical conductivity; $\mathrm{CE}^{(1)}$ : $\mathrm{CE}$ in $\mathrm{A}$ horizon $\mathrm{CE}^{(2)}$ : average values of $\mathrm{CE}$ between 20 to $60 \mathrm{~cm}$ of soil depth.

of clusters per plant was counted during the maturation period. The average weight of the cluster (g) was established, using a scale within 0.1 gram of precision, on five clusters harvested per plant. As a product of these two parameters, the yield per plant was calculated and the yield per hectare $(\mathrm{kg})$ was estimated. Four shoots per plant were removed, including the lateral developments of these, with the aim of defining the average leaf area per shoot or vine with an LI3100 leaf area index meter (LICOR, Inc. Lincoln, Nebraska USA). The number of shoots per plant was registered during the winter. The total leaf area per plant $\left(\mathrm{m}^{2}\right)$ was established as the product between leaf area per shoot and the number of shoots per plant. Based on this and considering the plantation distances, the number of plants per hectare was established and leaf area index (LAI) was calculated. As well, the trunk diameter was measured $(\mathrm{cm})$, prior to the first bifurcation of the same, corresponding to the first wire of the trellis and the fresh weight of pruning material from wood of one year $\left(\mathrm{kg} \mathrm{plant}^{-1}\right)$. As variables indicative of balance, the ratio between leaf area and the yield per plant $\left(\mathrm{m}^{2} \mathrm{~kg}^{-1}\right)$ was established, as well as the Ravaz index, as the quotient between yield and the weight of the pruning material of each plant.
For each variety, a variance analysis (ANOVA) of only one factor was conducted, as well as mean comparison for the crop variables according to each soil group by Tukey-Kramer test for unbalanced models (models with an unequal number of replicates), with a significance of $0.05 \%$. The GLM procedure of the SAS Statistical Program (SAS Institute, 2000) was used for this.

\section{RESULTS AND DISCUSSION}

\section{Vegetative and productive parameters}

The three varieties growing in soils of group 1, dominated by Durinodic and Aquic Natrargids, both with fine silty texture family (Tables 2, 3 and 4) presented the lowest levels of production, due to a lower number and weight of clusters per plant. The leaf area, represented by a lower number of shoots of individual development more scarce per plant, showed a similar behavior. As well, a lower development of the vines was evidenced in soils of group 1, based on the reduced weight of pruning material obtained from the three varieties and by the lower trunk diameter of cvs. Merlot (Table 2) and Cabernet Sauvignon (Table 4). This last aspect implied evaluating not only characteristics of the 
Table 2. Vegetative and productive performance of cv. Merlot. Season 2002-2003 (mean values for each soil groups). Cuadro 2. Comportamiento vegetativo-productivo del cv. Merlot. Período 2002-2003 (valores medios para cada grupo de suelos).

\begin{tabular}{|c|c|c|c|c|c|c|}
\hline \multirow[t]{2}{*}{ Variables } & \multicolumn{5}{|c|}{ Soil Groups } & \multirow{2}{*}{$\begin{array}{c}\text { P } \\
\text { Value }\end{array}$} \\
\hline & Group 1 & Group 2 & Group 3 & Group 5 & Site 9 & \\
\hline \multicolumn{7}{|l|}{ Per plant } \\
\hline Yield, kg plant ${ }^{-1}$ & $2.26 \mathrm{~b}$ & $5.01 \mathrm{a}$ & $5.16 \mathrm{a}$ & $2.31 \mathrm{ab}$ & $2.57 \mathrm{ab}$ & 0.0053 \\
\hline Number of vines plant ${ }^{-1}$ & $13.3 \mathrm{~b}$ & $20 \mathrm{a}$ & $21 \mathrm{a}$ & $16 \mathrm{ab}$ & $18 \mathrm{ab}$ & 0.0003 \\
\hline Leaf area, $\mathrm{m}^{2}$ plant $^{-1}$ & $3.04 \mathrm{~b}$ & $6.88 \mathrm{a}$ & $6.22 \mathrm{a}$ & $3.54 \mathrm{ab}$ & $4.42 \mathrm{ab}$ & 0.0003 \\
\hline Pruning material, $\mathrm{kg}$ plant ${ }^{-1}$ & $0.212 \mathrm{~b}$ & $0.500 \mathrm{a}$ & $0.388 \mathrm{ab}$ & $0.196 \mathrm{ab}$ & $0.173 \mathrm{ab}$ & 0.0041 \\
\hline Trunk diameter, $\mathrm{cm}$ & $5.11 \mathrm{~b}$ & $7.23 \mathrm{a}$ & $6.49 \mathrm{ab}$ & $6.52 \mathrm{ab}$ & $6.42 \mathrm{ab}$ & 0.0021 \\
\hline \multicolumn{7}{|l|}{ Per hectare } \\
\hline Yield, $\mathrm{kg} \mathrm{ha}^{-1}$ estimated & $5645.4 \mathrm{~b}$ & $12524.6 \mathrm{a}$ & $12891.7 \mathrm{a}$ & $5775.0 \mathrm{ab}$ & $6425.0 \mathrm{ab}$ & 0.0053 \\
\hline Leaf area index, $\mathrm{m}^{2} \mathrm{ha}^{-1}$ & $6332.3 \mathrm{~b}$ & $14331.0 \mathrm{a}$ & $12956.90 \mathrm{a}$ & $7373.8 \mathrm{ab}$ & $9206.90 \mathrm{ab}$ & 0.0003 \\
\hline \multicolumn{7}{|l|}{ Balance Index } \\
\hline Ravaz index & $19.58 \mathrm{a}$ & $10.94 \mathrm{a}$ & $15.29 \mathrm{a}$ & $12.41 \mathrm{a}$ & $14.07 \mathrm{a}$ & 0.4706 \\
\hline Leaf area/yield, $\mathrm{m}^{2}$ plant $^{-1}$ & $2.11 \mathrm{a}$ & $1.93 \mathrm{a}$ & $1.45 \mathrm{a}$ & $1.58 \mathrm{a}$ & $2.47 \mathrm{a}$ & 0.8954 \\
\hline
\end{tabular}

Averages with distinct letters in the same row are significantly different according to the Tukey-Kramer test $(\mathrm{P}<0.05)$. This variety was not in Group 4.

Table 3. Vegetative and productive performance of cv. Malbec in season 2002-2003 (mean values of each soil groups).

Cuadro 3. Comportamiento vegetativo-productivo del cv. Malbec. Ciclo 2002-2003 (valores medios para cada grupo de suelos).

\begin{tabular}{|c|c|c|c|c|c|c|}
\hline \multirow[t]{2}{*}{ Variables } & \multicolumn{5}{|c|}{ Soil Groups } & \multirow{2}{*}{$\begin{array}{c}\mathbf{P} \\
\text { Value }\end{array}$} \\
\hline & Group 1 & Group 2 & Group 3 & Group 4 & Group 5 & \\
\hline \multicolumn{7}{|l|}{ Per plant } \\
\hline Yield, kg plant ${ }^{-1}$ & $0.461 \mathrm{~b}$ & $1.73 \mathrm{ab}$ & $2.69 \mathrm{ab}$ & $2.8 \mathrm{a}$ & $0.573 \mathrm{ab}$ & 0.0083 \\
\hline Number of vines plant ${ }^{-1}$ & $7.7 \mathrm{~b}$ & $17 \mathrm{a}$ & $16.5 \mathrm{a}$ & $21.3 \mathrm{a}$ & $7 \mathrm{~b}$ & 0.0087 \\
\hline Leaf area, $\mathrm{m}^{2}$ plant $^{-1}$ & $0.499 \mathrm{c}$ & $3.60 \mathrm{ab}$ & $4.20 \mathrm{ab}$ & $5.91 \mathrm{a}$ & $1.10 \mathrm{cb}$ & 0.0144 \\
\hline Pruning material, $\mathrm{kg}$ plant ${ }^{-1}$ & $0.041 \mathrm{~b}$ & $0.264 \mathrm{ab}$ & $0.341 \mathrm{ab}$ & $0.466 \mathrm{a}$ & $0.062 \mathrm{~b}$ & 0.0074 \\
\hline Trunk diameter, $\mathrm{cm}$ & $5.04 \mathrm{ab}$ & $5.68 \mathrm{ab}$ & $5.37 \mathrm{ab}$ & $6.39 \mathrm{a}$ & $3.24 \mathrm{~b}$ & 0.0026 \\
\hline \multicolumn{7}{|l|}{ Per hectare } \\
\hline Yield, $\mathrm{kg} \mathrm{ha}^{-1}$ & $1152.5 \mathrm{~b}$ & $4336.7 \mathrm{ab}$ & $6730.2 \mathrm{ab}$ & $7020.8 \mathrm{a}$ & $1433.3 \mathrm{ab}$ & 0.0083 \\
\hline Leaf area index, $\mathrm{m}^{2} \mathrm{ha}^{-1}$ & $1039.4 \mathrm{c}$ & $7498.8 \mathrm{ab}$ & $8748.6 \mathrm{ab}$ & $12310.5 \mathrm{a}$ & $2291.3 \mathrm{cb}$ & 0.0144 \\
\hline \multicolumn{7}{|l|}{ Balance Index } \\
\hline Ravaz index & $14.55 \mathrm{a}$ & $6.05 \mathrm{a}$ & $9.45 \mathrm{a}$ & $6.01 \mathrm{a}$ & $9.60 \mathrm{a}$ & 0.2383 \\
\hline Leaf area/yield, $\mathrm{m}^{2}$ plant $^{-1}$ & $1.99 \mathrm{a}$ & $2.30 \mathrm{a}$ & $1.68 \mathrm{a}$ & $2.11 \mathrm{a}$ & $2.06 \mathrm{a}$ & 0.0490 \\
\hline
\end{tabular}

Averages with distinct letters in the same row are significantly different according to the Tukey-Kramer test $(\mathrm{P}<0.05)$. This variety was not in Site 9.

cultivars during the season under study, but also the possibility of growth that these vines have had over all or a great part of their growth period through the characteristics of their long-term structure. The role attributed to this structure in yield and maturation is well-known (Carbonneau, 2000).

The leaf area index, which reflects the degree of efficient land use, revealed scarce use of available surface in the sites belonging to group 1. Measurements were made of 13.3 and 7.7 shoots plant $^{-1}$ in Merlot (Table 2) and Malbec (Table 3 ) respectively. Considering that the distance between plants in the row is $2 \mathrm{~m}$, this would indicate an average separation of 15 and $26 \mathrm{~cm}$ for each situation (while recognizing that they are in a two-tier system of 4 canes, and that there are gaps or open spaces between plants), a situation far from the spacing of 7 to $10 \mathrm{~cm}$ indicated 
Table 4. Vegetative and productive performance of cv. Cabernet Sauvignon in season 2002-2003 (mean values of each soil groups).

Cuadro 4. Comportamiento vegetativo-productivo de Cabernet Sauvignon. Ciclo 2002-2003 (valores medios para cada grupo de suelos).

\begin{tabular}{|c|c|c|c|c|}
\hline \multirow[t]{2}{*}{ Variables } & \multicolumn{3}{|c|}{ Soil groups } & \multirow{2}{*}{$\begin{array}{c}\mathbf{P} \\
\text { value }\end{array}$} \\
\hline & Group 1 & Group 2 & Group 3 & \\
\hline \multicolumn{5}{|l|}{ Per plant } \\
\hline Yield, kg plant ${ }^{-1}$ & $2.13 \mathrm{~b}$ & $3.95 \mathrm{a}$ & $3.9 \mathrm{ab}$ & 0.0032 \\
\hline Number of vines plant ${ }^{-1}$ & $17.9 \mathrm{~b}$ & $24.4 \mathrm{ab}$ & $32.9 \mathrm{a}$ & 0.0188 \\
\hline Leaf area, $\mathrm{m}^{2}$ plant $^{-1}$ & $3.34 \mathrm{~b}$ & $5.54 \mathrm{ab}$ & $5.97 \mathrm{a}$ & 0.0257 \\
\hline Pruning material, kg plant $\mathrm{k}^{-1}$ & $0.373 \mathrm{~b}$ & $0.730 \mathrm{ab}$ & $0.757 \mathrm{a}$ & 0.0236 \\
\hline Trunk diameter, $\mathrm{cm}$ & $6.80 \mathrm{~b}$ & $8.54 \mathrm{a}$ & $9.77 \mathrm{a}$ & 0.0003 \\
\hline \multicolumn{5}{|l|}{ Per hectare } \\
\hline Yield, kg ha-1 & $5323.95 \mathrm{~b}$ & $9875.28 \mathrm{a}$ & $9753.61 \mathrm{ab}$ & 0.0032 \\
\hline Leaf area index, $\mathrm{m}^{2} \mathrm{ha}^{-1}$ & $6957.22 \mathrm{~b}$ & $11539.82 \mathrm{ab}$ & $12435.51 \mathrm{a}$ & 0.0257 \\
\hline \multicolumn{5}{|l|}{ Balance Index } \\
\hline Ravaz index & $6.84 \mathrm{a}$ & $9.25 \mathrm{a}$ & $5.36 \mathrm{a}$ & 0.2262 \\
\hline Leaf area/yield, $\mathrm{m}^{2}$ plant $^{-1}$ & $1.57 \mathrm{a}$ & $1.35 \mathrm{a}$ & $2.18 \mathrm{a}$ & 0.5438 \\
\hline
\end{tabular}

Averages with distinct letters in the same row are significantly different according to the Tukey-Kramer test $(\mathrm{P}<0.05)$. This variety was not in Group 4, Group 5 and Site 9.

by Smart (1988) as optimal to achieve an adequate balance between production and maturation. This author argues that less distancing supposes excessive shading of leaves and clusters, and greater values implies a low interception of light and a scarce number of shoots per hectare, which means less production. For his part, White (2003) states that low indices of leaf area imply that a high proportion of total evapotranspiration is based on the evaporation from the soil. This factor then is added to reduced effective depth and high resistance to penetration (Table 1), limiting even more water availability to be utilized in the transpiration processes of the plants, constituting another restriction of these soils for normal growth.

The values obtained for each variable analyzed to this point in group 1, were always similar to those of group 5, Aquic Durinodic Haplocalcids, with a coarse loamy textural family. Both groups share the presence of thick and extremely hard horizons, less than $33 \mathrm{~cm}$ from the surface, with values for resistance to penetration of 3.13 and $3.36 \mathrm{MPa}$, respectively (Table 1 ). These values exceed the 2.7 $\mathrm{MPa}$ that Theadgill (1982) considers as admissible for vegetal growth, as well as the $3 \mathrm{MPa}$ described by White (2003) as limiting for vines, who cites values less than $2 \mathrm{MPa}$ as acceptable. These hardened layers, with silt loam and loam soil textural classes have bulk density values of between 1.5 and $1.9 \mathrm{~g}$ $\mathrm{cm}^{-3}$ and with aeration porosity of less than $10 \%$ (Apcarian et al., 1997), which does not reach the range of $10-15 \%$ indicated by White (2003) as desirable to allow for the diffusion of $\mathrm{O}_{2}$ and $\mathrm{CO}_{2}$. The combination of a high resistance to penetration and minimal aeration porosity of densified horizons limits radicular growth, being maximum upon greater thickness of these layers and the closer to the surface they are found. If it is considered that authors such as Hunter and Archer (2001a) and White (2003) maintain that the vines extend their roots to a range of depth of between 40-60 or 40-80 $\mathrm{cm}$, and that the depth of the soils in groups 1 and 5 do not exceed the minimal values cited, then the reduced production of fruit, wood and leaf area can be attributed mainly to the scarce volume of soil easily explorable by the roots.

The vines that developed in group 2 soils (Aquic and Durinodic Natrargids, with a fine silty textural family) and of group 3 (Aquic and Typic Haplocambids, with contrasting texture, a fine silty on coarse loamy) did not differentiate from each other in any of the variables evaluated for each cultivar (Tables 2, 3 and 4). Both groups have higher levels of fruit production, weight of pruning material and leaf area than group 1, but did not reach levels to significantly differentiate themselves from group 5. This situation can be attributed however to the presence of hardened horizons occurring at 
similar depths, which were of a lower thickness and with lower values for resistance to penetration $(<2.7 \mathrm{MPa})$ (Table 1), making a greater volume of soil explorable by the roots. The values for yields per hectare correspond to figures considered average to high for vineyards in the region of study (Leskovar et al., 1998). In Merlot (Table 2) the vines of these soils reached average levels of leaf area per plant, which doubled the values obtained in group 1 and with 20 shoots per plant (group 2) and 21 (group 3). In Malbec (Table 3 ) the differences to the vines in group 1 were even more marked, with 17 (group 2) and 16.5 (group 3) shoots per plant. With Cabernet Sauvignon (Table 4) the number of shoots per plant was 17.9, 24.4 and 32.9 for groups 1, 2 and 3, respectively.

Group 4 of Durinodic Haplocambids, with a coarse silty textural family, was not detected in the sites studied with Merlot. Results with the Cabernet Sauvignon are not presented owing to the loss of data relating to pruning material and the number of shoots per plant. The cv. Malbec has production values and leaf area similar to those of groups 2 and 3 (Table 3 ). Those soils have densified and/or hardened horizons of more than $50 \mathrm{~cm}$, and with values $<2.7 \mathrm{MPa}$, together with thicker A horizons and with a greater level of organic material than the others (Table 1). The salinity present in these soils, of a value greater than $8 \mathrm{dS} \mathrm{m}^{-1}$ (Table 1), could be an influencing factor why the cultivar is not significantly differentiated from groups 2 and 3 in its productive and vegetative parameters (Table 3). May (1994) and Cass (1998) as cited by White (2003) refers to a reduction of 25 to $50 \%$ of production in moderately salinated soils (4-8 dS $\left.\mathrm{m}^{-1}\right)$.

\section{Balance Index}

Both the Ravaz Index and the leaf area per plant/ yield ratio per plant did not show significant differences among the groups for the three varieties (Tables 2,3 and 4), indicating that the vines present similar levels of balance at each level of vegetative and productive expression obtained for each soil group.

Considering authors as Howell (2001), who mention values of 7 to $14 \mathrm{~cm}^{2}$ of leaf area per gram of ripen fruit, the three cultivars in the evaluated conditions had enough leaf area as to ripen adequately the production level.
Considering values between 3 and 10 as acceptable for the Ravaz index (Cavagnaro et al., 1997; Main et al., 2002), and values of 5-7 as optimal (Ravaz, 1903, as cited by Vasconcelos and Castagnoli, 2001), it can be said that Cabernet Sauvignon (Table 4) presented an adequate level of balance in the three groups of soils analyzed. In Malbec (Table 3), while the differences were not significant, a higher value of their index in group 1 would indicate a certain weakening of the vines cultivated in these soils, while with the Merlot (Table 2) all the groups showed a weakening of the vines, tending to be accentuated in group 1, owing to the low weight of the pruning material given the yield of the group.

These results indicate that although in soils with superficial hardened horizons, with a low winegrowing potential, such as those of groups 1 or 5 , an adequate balance can be obtained, as occurs with the vines of Cabernet Sauvignon (Table 4) that are developed in soils of the group 1, and with Malbec plants (Table 3) that grow in soils of group 5. Therefore, the weakening evidenced by Merlot through the elevated Ravaz indices in all of the groups (Table 2) and for Malbec (Table 3) in group 1 , could be attributed to other properties of the soils or to aspects related to the management of the vines. White (2003) argues that cultural practices such as irrigation, fertilization, pruning or the canopy management, clearly interact with the soil and the environment to determine balanced vines. Knowing the role of the organic matter and nitrogen content in the vegetative growth of the vine, it could be estimated that the low level of organic matter and of nitrogen in these soils would have some incidence in the observed performance.

\section{CONCLUSIONS}

The production of the cultivars was associated with soil characteristics. The depth, thickness and penetration resistance of hardened horizons affected the vegetative and productive potential of Merlot, Malbec and Cabernet Sauvignon cultivars.

In the three cultivars the level of yield, leaf area and the weight of pruning material per plant were reduced when the soils had extremely hard horizons, with a resistance to penetration greater than $3 \mathrm{MPa}$ in low depth ( $35 \mathrm{~cm}$ or less from the surface) and with 30 $\mathrm{cm}$ or more of thickness, allowing to characterize these soils as having a low wine-growing potential. 
The Ravaz index and the leaf area/yield ratio were not sensitive to these properties of the soil. Similar relations of vegetative-productive balance were maintained among the soil groups, although pertaining to sites of different wine-growing potentials.

Among the soil groups with properties that limit the potential of the site, but that allow for an adequate vegetative-productive balance, less spacing between vines can be used to increase yield per hectare and avoiding gaps or empty spaces between them, thus optimizing the efficient use of the land.

\section{ACKNOWLEDGEMENTS}

Our thanks to the Agriculture Engineers J.M. Vidiri and F. Fournieles of the Establecimiento Humberto Canale S.A. for their valuable cooperation in the activities carried out in the vineyard of the aforementioned company.

This work was developed in the framework of the Research Project PI 04/A070 "Spatial Variability of Soils with Hardened Horizons in Alto Valle of Río Negro", financed by the Research Secretariat of Universidad Nacional del Comahue and Establecimiento H. Canale S.A., with cooperation from the Autoridad Interjurisdiccional de Cuencas (AIC) of the Rivers Limay, Neuquén and Río Negro, Argentine.

\section{LITERATURE CITED}

Apcarian, A., M.C. Echenique, M.C. Aruani, y P. Reeb. 2006. Efecto de capas endurecidas de suelos sobre el potencial productivo de viñedos, Alto Valle de Río Negro, Patagonia, Argentina. Agric. Téc. (Chile) 66:70-79.

Apcarian, A., P. Schmid, G. Polla, y P.A. Imbellone. 1997. Suelos con horizontes endurecidos en el Alto Valle de Río Negro, Argentina. p. 60. In VIII Congreso Nacional de la Ciencia del Suelo, La Serena, Chile. 06-09 de agosto de 1997. Sociedad Chilena de la Ciencia del Suelo, Santiago, Chile.

Carbonneau, A. 2002. Elementos de la conducción de la viña que favorecen la protección del terruño y la expresión de sus vinos. In ACE Revista de Enología Vol. 22 Junio 2002. (On line). Available at http:// www.acenologia.com/ciencia59_03.htm Accessed 4 July 2004.

Cavagnaro, R. de, J. Rodríguez, H. Ojeda, C. Catania, y S. Del Monte. 1997. Manejo de la canopia de cepas cv. Chardonnay (Vitis vinifera L.) y su efecto sobre la expresión vegetativa, rendimiento, composición del fruto y características del vino. XXII Congres de la Vigne et du Vin. Buenos Aires. 1-5 de diciembre de 1997. Office Internacional de la Vigne et du Vin, Buenos Aires, Argentina.

Flores, L. 2005. Variabilidad espacial del rendimiento de uva y calidad del mosto en cuarteles de vid cv. Cabernet Sauvignon y Chardonnay en respuesta a la variabilidad de algunas propiedades del suelo. Agric. Téc. (Chile) 65:210-220.
Gómez-Miguel, V., y V. Sotés Ruiz. 2000. Utilización de los estudios detallados y muy detallados de suelos en la microzonificación vitícola. 8 p. Tomo II. In Proc. III Simposio Internacional de Zonificación Vitícola, Puerto de la Cruz, Tenerife, España. 09-12 mayo 2000. GESCO (Groupe d'Etude des Systèmes de Conduite de la Vigne) y OIV (Office International de la Vigne et du Vin), España.

Howell, G.S. 2001. Sustainable grape productivity and the growth-yield relationship: A review. Am. J. Enol. Vitic. 52:165-174.

Hunter, J.J., and E. Archer. 2001a. Long term cultivation strategies to improve grape quality. 24 p. In Proc. VIII Viticulture and Enology Latin American Congress. Montevideo, Uruguay. 12-16 nov. 2001. Asociación de Enólogos de Uruguay, Instituto Nacional de Vitivinicultura (INAVI) y Organización Internacional de la Viña y el Vino (IOV), Montevideo, Uruguay. Available at www.uruguayxxi.gub.uy Accessed 4 july 2004.

Hunter, J.J., and E. Archer. 2001b. Short term cultivation strategies to improve grape quality. 16 p. In Proc. VIII Viticulture and Enology Latin American Congress. Montevideo, Uruguay. 12-16 nov. 2001. Asociación de Enólogos de Uruguay, Instituto Nacional de Vitivinicultura (INAVI) y Organización Internacional de la Viña y el Vino (IOV), Montevideo, Uruguay. Available at www.uruguayxxi.gub.uy Accessed 4 july 2004. 
Kobus, C. 2002. Soil type may influence wine style: Cabernet Sauvignon from Durbanville and Robertson. 7 p. In Wineland Nov. 2002. (On line). Available at http://www.wynboer.co.za/recentarticles/1102 soil.php3 Accessed 1 January 2004.

Leskovar, M., M. Echenique, M. Cerutti, y O. Alvarez. 1998. Caracterización de la actividad vitivinícola de Río Negro y Neuquén. Viticultura y Enología Profesional. AGROLATINO (Barcelona, España) 10(58):6-14.

Main, G., J. Morris, and K. Striegler. 2002. Rootstock effects on Chardonel productivity, fruit, and wine composition. Am. J. Enol. Vitic. 53:37-40.

Ruiz, R. 2000. Dinámica nutricional en cinco parrones de diferente productividad del valle central regado de Chile. Agric. Téc. (Chile) 60:379-398.

SAS Institute. 2000. SAS On line DOC, Version 8. CD. SAS Institute Inc., Cary, North Carolina, USA.

Schoeneberger, P.A., D.A. Wysocki, E.C. Benham, and W.D. Borderson. 1998. Libro de campaña para descripción y muestreo de suelos. Versión 1.1. 155 p. Centro Nacional de Relevamiento de Suelos, Servicio de Conservación de Recursos Naturales, Dpto. de Agricultura de los EE.UU., Lincoln, Nebraska. Traducción al español. Área de Cartografía de Suelos y Evaluación de Tierras, Centro de Recursos Naturales, Instituto Nacional de Tecnología Agropecuaria, Castelar, Argentina.
Servicio Meteorológico Nacional. 1992. Estadísticas meteorológicas Años 1981-1990. 709 p. Serie B N ${ }^{\circ}$ 37. Servicio Meteorológico Nacional, Buenos Aires, Argentina.

Smart, R. 1988. Shoot spacing and canopy light microclimate. Am. J. Enol. Vitic. 33:99-108.

Smart, R., J.B. Robinson, G.R. Due, and C.J. Brien. 1985. Canopy microclimate modification for the cultivar Shiraz. I. Definition of canopy microclimate. Vitis 24:17-31.

Soil Survey Staff. 1996. Keys to soil taxonomy. 644 p. $7^{\text {th }}$ ed. USDA, Natural Resources Conservation Service. Agric. Handb. 436. U.S. Gov. Print Office, Washington DC, USA.

Theadgill, E.D. 1982. Residual tillage effects as determined by cone index. Trans. ASAE 25:859-963.

United States Salinity Laboratory Staff. 1954. Diagnosis and improvement of saline and alkali soils. $160 \mathrm{p}$. USDA Soil and Water Conservation Research Branch. Agriculture Research Service. Handb. 60. U.S. Gov. Print Office, Washington, DC, USA.

Vasconcelos, M.C., and S. Castagnoli. 2001. Leaf canopy structure and vine performance. Am. J. Enol. Vitic. 51:390-396.

White, R.E. 2003. Soils for fine wine. 279 p. Oxford University Press, New York, USA. 